\title{
Imaginário religioso e persistência: estudo dos ritos mortuários judeus à luz da Inquisição portuguesa nas minas setecentistas ${ }^{1}$
}

\author{
Religious imagery and persistense: study of jews mortuary rites in the light of the \\ Portuguese inquisition in eighteenth-century Minas
}

Rudney Avelino de Castro Silva ${ }^{2}$

\begin{abstract}
Resumo
Entre os séculos XVI e XVIII, a Inquisição portuguesa promoveu intensa perseguição àqueles que fossem descobertos cometendo desvios contra os costumes da Igreja, punições que eram aplicadas tanto aos que residiam no reino como os que se encontravam nas colônias. Porém, a maior parte dos processos do período da Inquisição é encontrada em arquivos da primeira metade do século XVIII; não coincidência, no auge da exploração aurífera das Minas Gerais. Este trabalho tem por intuito apresentar alguns resultados da análise documental (inventários, testamentos e processos inquisitoriais) de processados pelo Tribunal de Inquisição, com destaque para os acusados de judaísmo e que eram moradores da cidade de Sabará-MG. Os processos analisados mostraram a solicitação, por parte dos réus, de ritos mortuários que foram considerados práticas judaizantes e, por isso mesmo, veementemente reprimidas e combatidas. A principal solicitação dos réus, e que foi reincidente nos testamentos, foi o uso de mortalha. Ainda que o uso da mortalha tenha sido uma prática condenada pelos inquisidores, uma vez que comprovaria a ligação ao judaísmo, é no mínimo curioso quando percebemos que também pertenceu às tradições cristãs. Fazemos aqui uma reflexão do imaginário religioso revelado nessas tradições e buscamos compreender suas nuances, analisar as descontinuidades e permanências e explicar as transformações de sentido ao longo do tempo e responder o porquê de terem sido criminalizadas e perseguidas.
\end{abstract}

Palavras-chave: ritos mortuários; inquisição portuguesa; judaísmo

\begin{abstract}
Between the sixteenth and eighteenth centuries, the Portuguese Inquisition promoted intense persecution of those found to be deviating from the Church's customs, punishments that were applied both to those who resided in the kingdom and those who were in the colonies. However, most processes from the period of the Inquisition are found in archives from the first half of the 18th century; no coincidence, at the height of gold mining in Minas Gerais. This work aims to present some results of the documentary analysis (inventories, wills and inquisitorial processes) of those processed by the Court of Inquisition, with emphasis on those accused of Judaism and who were residents of the city of Sabará-MG. The analyzed cases showed the request, by the defendants, of

\footnotetext{
${ }^{1}$ Trabalho sob orientação da Dra. Júlia Calvo

${ }^{2}$ Mestre em Ciências Sociais pelo Programa de Pós Graduação em Ciências Sociais da PUC Minas. Pesquisador Colaborador no Centro em Rede de Investigação em Antropologia (CRIA-IUL). E-mail: rudcastro86@gmail.com
} 
mortuary rites that were considered Judaizing practices and, therefore, vehemently repressed and fought. The defendants' main request, which was repeated in the wills, was the use of a shroud. Although the use of the shroud was a practice condemned by the inquisitors, since it would prove the connection to Judaism, it is at least curious when we realize that it also belonged to Christian traditions. We reflect here on the religious imagery revealed in these traditions and seek to understand its nuances, analyze discontinuities and permanences and explain the transformations of meaning over time and answer why they were criminalized and persecuted.

Keywords: mortuary rites; - Portuguese inquisition; - Judaism

O tribunal do Santo Ofício, em Portugal, funcionou em Lisboa, Coimbra e Évora ${ }^{3}$, atuando durante os séculos XVI e XIX com justificativa religiosa e atitude política, numa aliança entre Igreja e Estado. Os réus brasileiros, como os estudos da Inquisição no país já indicaram, foram todos julgados em Lisboa, sede do Império português.

A Inquisição compõe, no caso Ibérico, o processo de formalização do Estado Absolutista, implicando, assim, numa relação intrínseca com o Estado português, que se apoiou na moral religiosa católica como forma de construção nacional muito específica que pode ser compreendida na própria constituição das nações ibéricas realizada com a expulsão dos mouros durante as Guerras de Reconquista.

A Inquisição teve um papel fundamental de dar alento às massas (e ao próprio baixo clero) e de criar estratégias para a estrutura de poder, atendendo aos interesses do rei e dos grupos de poder, estabelecendo uma unidade capaz de dar sustentação à consciência coletiva para a constituição e para o reconhecimento nacional.

A Inquisição, assim, materializava um imaginário de nação católica (que combatia todo e qualquer ameaça à nova ordem) que se firmava pelo medo imposto à sociedade da ação demoníaca, como veremos ao longo do trabalho.

Com relação à presença judaica na América colonial portuguesa, a Inquisição estabeleceu, pela força do medo, do segredo e da tradição, a formação de um grupo singular que contribuiu culturalmente para a própria noção da brasilidade (no caso aqui, mais delimitada como mineiridade) de nossa população.

As estratégias culturais de sobrevivência do grupo em terras brasileiras vai definir todo um arcabouço de hábitos e formas de ver o mundo e, consequentemente, traduzir para a realidade traços de uma cultura híbrida, construída sob os temores, mas, também, sob as perspectivas de assimilação e enraizamento.

\footnotetext{
${ }^{3}$ Além desses registra-se, também, a existência de tribunais em Porto, Lamego e Tomar, porém, estes três tiveram curta duração.
} 


\section{Registros da presença judaica em Sabará-MG}

Este artigo se pautou na pesquisa desenvolvida por CALVO e SILVA (2012) que investigou as marcas judaicas no Brasil, especialmente localizadas na cidade de Sabará, em Minas Gerais, com base nos inventários e testamentos de réus residentes listados por Novinsky (2002) em Inquisição: Os prisioneiros do Brasil.

Os inventários são importantes ao registrar os bens e as dívidas, mas também o registro de pertencimento às irmandades. Os testamentos também foram importantes para identificar os pedidos acerca dos rituais pós morte, como a solicitação do uso de mortalha. Naquela pesquisa foram analisados e sistematizados 25 inventários e testamentos dos réus culpados de judaísmo e em 18 testamentos deles foi encontrada a solicitação do uso da mortalha.

Como estabelece a tabela a seguir, foram 15 homens e 3 mulheres, sendo 2 de exescravas, sendo possível identificar a ligação com as irmandades leigas como no quadro abaixo: 
Inventários analisados: processados de Sabará

\begin{tabular}{|c|c|c|}
\hline Documentos analisados & 25 & $\begin{array}{l}\text { Dentre estes, alguns são Inventários, nos quais } \\
\text { não se encontram informações relacionadas a } \\
\text { esse traço cultural. Porém, em todos os } \\
\text { Testamentos analisados encontram-se } \\
\text { informações sobre a mortalha. }\end{array}$ \\
\hline $\begin{array}{c}\text { Documentos que citam a } \\
\text { mortalha }\end{array}$ & 18 & $\begin{array}{l}\text { Destes, um não cita a mortalha, pede que seu } \\
\text { corpo seja envolto em um hábito de São Pedro e } \\
\text { este é o testamento de um Padre. }\end{array}$ \\
\hline Testamentos de Mulheres & 3 & \\
\hline Testamentos de Homens & 15 & \\
\hline Testamentos de Pretas Forras & 2 & \\
\hline $\begin{array}{l}\text { Solicitação de mortalha em } \\
\text { hábito de São Francisco }\end{array}$ & 14 & \\
\hline $\begin{array}{l}\text { Solicitação de mortalha em } \\
\text { lençol/bestanha ou outros } \\
\text { hábitos }\end{array}$ & 4 & \\
\hline $\begin{array}{l}\text { Pertencentes a Irmandade das } \\
\text { Almas }\end{array}$ & 8 & \multirow{3}{*}{$\begin{array}{l}\text { Outras Irmandades citadas são: Nossa Senhora } \\
\text { do Amparo, Nossa Senhora do Rosário, Nossa } \\
\text { Senhora da Conceição, Irmandade das Palavras, } \\
\text { Santo Antônio. }\end{array}$} \\
\hline $\begin{array}{l}\text { Pertencentes a Irmandade do } \\
\text { Santíssimo Sacramento }\end{array}$ & 3 & \\
\hline $\begin{array}{l}\text { Não cita relação com } \\
\text { Irmandades }\end{array}$ & 5 & \\
\hline
\end{tabular}

(CALVO e SILVA, 2012)

Em alguns testamentos analisados era solicitada a mortalha de lençol ou bestanha, porém, em 14 desses testamentos, o amortalhamento foi solicitado em hábito de São Francisco ${ }^{4}$, o preferido e citado também em estudos sobre a morte na Bahia de João José Reis (1991) e Adalgisa Arantes Campos (1988).

\footnotetext{
${ }^{4}$ Para Reis, a mortalha e o uso do hábito de S. Francisco remetem a um costume português, difundido principalmente no Brasil por mulheres. Já para Campos, que também aponta a recorrência de sua solicitação em vários testamentos das minas Setecentistas “a mortalha era outro símbolo social exterior. (...) As mortalhas eram caras e os que não se encontravam preparados para este gasto tinham que se contentar com um lençol” (1988, p. 17), já indicando as formas de apropriação de seu uso na cultura brasileira.
} 
Os documentos inquisitoriais analisados reforçam a perseguição aos judaizantes. É interessante notar, porém, que a culpa de judaísmo extrapolava à existência de laços sanguíneos dos cristãos novos como indica processados de origem africana. A presença de escravas/pretas forras com culpa de judaísmo e que residiram em Sabará nos leva a questionar as práticas dos acusados como judaizantes (como indicam os inquisidores nos processos analisados), mas afirmá-las como tradição cultural. Todos os processos carregam na denúncia a culpa de judaísmo e as inquirições dão conta de práticas e hábitos culturais relacionados à comida, à guarda do sábado, às tradições mortuárias e à crenças de modo geral.

Chama a atenção na documentação tanto a filiação dos réus às irmandades religiosas, como a solicitação da mortalha para seu sepultamento. As informações da vinculação às irmandades aparecem nos testamentos. Segundo Calvo e Silva (2019), os réus se vinculavam às seguintes irmandades: Irmandade das Almas, Irmandade do Santíssimo Sacramento, Nossa Senhora do Amparo, Nossa Senhora do Rosário, Nossa Senhora da Conceição, Irmandade das Palavras e Santo Antônio.

As Irmandades como formas de associativismo de caráter público ainda precisam de mais investigação para buscar identificar tradições ligadas à cultura judaica ou práticas judaizantes. Já a mortalha ${ }^{5}$, vestimenta de luto, é registrada como prática cultural e como tradição, mas apareceram como prática judaizante e prova para inquisição de que os réus eram sim culpados de judaísmo.

\section{Os ritos mortuários e a representação da morte no imaginário coletivo}

A questão da morte é fundante para o homem e suas sociedades. Traduz, geralmente, uma noção de finitude. No mundo ocidental traduz certezas e medos e tem um importante papel na vida cultural das sociedades humanas (CALVO E SILVA: 2019).

O que acontece após a morte é especulado pelas religiões e crenças variando no tempo. Cada cultura se despede dos seus entes queridos com respeito e, principalmente, de acordo com as visões do que acontece com o morto após sua passagem na terra. Quanto mais vivência dessa morte, com o experimentar das guerras e das pragas durante a crise

\footnotetext{
${ }^{5}$ A mortalha, usada no judaísmo, ainda hoje como parte de seu ritual mortuário, aparece em outros povos e culturas é também utilizada pelos árabes na atualidade e foi utilizada pelos cristãos durante o fim da antiguidade e do medievo, é importante registrar.
} 
do século XIV e o advento da modernidade, mais há preocupação com o que acontece após a morte, e recheia o imaginário do homem e das ideologias religiosas que dão sentido e materialidade.

Um bom exemplo é a invenção do purgatório como um terceiro lugar para acolher o homem e lhe permitir alçar o desejável céu:

\begin{abstract}
A invenção do purgatório reflete bem uma virada da mentalidade coletiva no seio da Idade Média moldada pela 'ordenação escolástica'. No decorrer do século XIII, levando a primeira promulgação do dogma do purgatório no Concílio de Lyon, em 1274. Os grandes teólogos da época, muitas vezes oriundos das novas ordens medicantes, São Boaventura, Alberto, o Grande, São Tomás de Aquino, dissertam e definem os contornos do novo local, deixando a seus sucessores dos séculos vindouros, atores da pastoral em ação, ou, pelo contrário, visionários como os grandes místicas alemães, Santa Gertrudes e Santa Mechtilde, o cuidado de enriquecê-lo e glosá-lo. A Igreja instituição, no quadro de uma polêmica travada com os gregos desde meados do século XVIII, definitivamente o dogma do purgatório no Concílio de Florença em 1439. (VOVELLE: 2008, P. 28)
\end{abstract}

Há como se explicita no trecho uma consolidação do ideal religioso e místico de uma forma sincrética, influenciado por vivências de outros grupos sobre a morte e mesmo sobre a possibilidade de existência de um terceiro lugar que vai se tornar o chamado purgatório.

Definir um lugar para o morto responde primordialmente a um medo da relação com o desconhecido e da possibilidade de convívio entre vivos e mortos. Outras crenças (como a celta, a escandinava e a escocesa) acreditam na presença dos mortos entre os vivos, vivendo a vida deles, mas rodeando os vivos e podendo aparecer em qualquer lugar. Esse encontro é sempre muito temido (VOVELLE: 2008, p. 31) e a relação com a morte é marcada assim por uma multiplicidade de gestos "mágicos" como presságios, orações, escritos na sepultura, práticas de sepultamento, cuidados pós morte, oferendas e outros com a intenção de apaziguar os mortos e mantê-los à distância.

No século XI começou a se popularizar na Europa cristã as lanternas dos mortos, altas coluna circulares ou hexagonais que foram construídas nos cemitérios inicialmente na França românica (VOVELLE: 2008, p. 40). Eram colunas cegas até o alto, quando vãos deixavam passar a luz de uma lanterna que as cobre e onde arde uma luz, provavelmente com a intenção de iluminar o caminho do morto e até segurar as almas no cemitério.

A morte e suas representações nas culturas por meio dos gestos e práticas tornamse públicas, e, portanto, objeto passível de investigação a partir da observação ou dos registros dos ritos de sepultamento e do luto. 
No caso dos judeus, é carregada de simbologia sobre a vida, sobre a sobrevivência da alma, sobre os valores judaicos que são ensinados e reforçados nas cerimônias fúnebres. Também envolto de rituais mágicos de proteção como o uso da mortalha, da prática de purificação do corpo e do lançar fora a água presente nos recipientes presentes na residência do morto.

Todas essas práticas funerárias foram apresentadas pelos inquisidores de Lisboa e colocaram em xeque a luta pela sobrevivência e liberdade dos réus. São atos que eram repetidos em família como tradição, nem sempre tradição religiosa, mas tradição de famílias amparadas nos gestos mágicos que explicitamos acima. Porém, num mundo assombrado pelo medo do demônio e que se colocava diante da proximidade do fim de toda existência, promoveu perseguição e morte.

Faremos, a partir daqui, uma análise da ritualística judaica da morte e a doutrina religiosa sobre a alma, os mortos e a relação com os vivos, para compreendermos a própria tradição e as explicações sobre a prática de amortalhar os mortos que coincidiu nos pedidos dos réus que foram moradores de Sabará.

Na tradição judaica, a morte afeta apenas o corpo físico, uma vez que termina sua missão terrestre, por isso a terra representa o repouso:

De acordo com as leis mosaicas, o corpo deve ser sepultado logo que for possível, de preferência no mesmo dia da morte e, também, enquanto houver luz natural: Seu cadáver não poderá permanecer ali durante a noite, mas tu o sepultarás no mesmo dia (Deuteronômio 21:23). Enquanto o morto permanecer insepulto, a sua alma não ficará em repouso. Ela só descansará quando o corpo for enterrado. (VAINSENCHER, 2009. P.1)

Corpo e alma são indissociáveis no judaísmo e é importante o cuidado aos mortos com observância a toalete e preparo para o sepultamento, assim como o cumprimento de todos os passos do luto seguindo rituais fúnebres dentro da simbologia judaica (CALVO E SILVA: 2019).

No caso dos cristãos novos, a associação da prática foi alvo da inquisição porque associava as práticas funerárias como indicativo de criptojudaismo, ou da atitude do judeu que se converteu ao Cristianismo durante os séculos XIV e XV, de continuar a manter os rituais e as práticas religiosas judaicas

No judaísmo, a preparação do corpo para o sepultamento deve respeitar algumas normas especiais. Se possível, o corpo deve ser sepultado no mesmo dia do falecimento, em terreno consagrado, seguindo a noção de que "o homem veio da terra e a ela deve retornar, e quanto mais rápido melhor”, pois a alma não descansará até o sepultamento do corpo. É proibido ver o corpo, 
procurando garantir que todos os judeus são iguais na morte, de modo que não se permita a ninguém "que o olhe e faça comparações com a aparência de um homem mais afortunado". Quando possível, o corpo deve ser depositado diretamente no solo, ou em ataúdes de tábuas simples, visto que a lei judaica condena a ostentação excessiva nos funerais. Por razões óbvias, nem todas estas práticas poderão ser mantidas ou seguidas pelos cristãos novos judaizantes, adaptando-se às possibilidades e conveniências em ambiente hostil, visto o seu caráter altamente denunciativo da manutenção criptojudaica por alguns neoconversos. Outra proibição existente é a de enterrar os corpos com joias ou objetos preciosos - exceção feitas a alianças de casamento. (ASSIS,:2012, p. 256-257)

No judaísmo acredita-se que com a vinda do Messias haverá uma ressureição dos mortos, o que, nas práticas de sepultamento, levam a necessidade do enterramento ser feito individualmente em terra virgem e que, ao receber o morto, torna-se consagrada, ao mesmo tempo em que não se permite o contato com o cadáver, o que também explicaria uma prática de denúncia inquisitorial, que era o juramento envolvendo falecidos (jurar pela alma de algum antepassado era corriqueiro entre as denúncias a judaizantes).

É importante ressaltar que essa prática do sepultamento em terra virgem e sepulturas individualizadas também era mantida por cristãos e teria sido relatada no próprio sepultamento de Cristo. Visto assim, os rituais fúnebres não são privilégio da sociedade que conhecemos, pelo contrário, estavam presentes no Neolítico, há cerca de cinco mil anos antes da era Cristã. No judaísmo, os primeiros sepultamentos eram feitos em cavernas e a partir de seu contato com os rituais egípcios, durante sua longa estada no período do $\hat{E}{ }^{\prime}{ }^{6}{ }^{6}$, novos gestos foram agregados aos seus ritos mortuários. Segundo Bayard:

Os hebreus, retomando a tradição egípcia, aprenderam a arte de embalsamar os corpos. Lavavam os cadáveres com muito cuidado, barbeavam-nos e os perfumavam com mirra e pó de aloés. Os membros eram atados com faixas; o corpo era recoberto com lençol, e o rosto, com pano. (1996, p. 103)

Há então, a primeira referência ao uso da mortalha entre os judeus ${ }^{7}$. O uso da mortalha permaneceu, e permanece ainda hoje, como parte importante do ritual de sepultamento judaico. Nessa tradição o período de luto é dividido em três momentos que

\footnotetext{
${ }^{6}$ Período que marca, na antiga História de Israel, a saída em massa dos judeus do Egito para o deserto e, posteriormente, à Terra Prometida.

${ }^{7}$ É importante salientar que o uso da mortalha também aparece nos rituais antigos da cultura cristã como iremos discutir no decorrer desse artigo.
} 
são repletos de orações, interdições e obrigações que vão diminuindo gradativamente com o passar do tempo (ZUCHIWSCHI, 2010, p. 168-169) ${ }^{8}$.

Segundo Calvo e Silva (2012), os serviços fúnebres são realizados, geralmente, pela Sociedade Sagrada (Chevra Kadisha), criada para a realização do funeral de Moisés, ou pelos amigos da família. Esses serviços iniciam-se com a lavagem completa do corpo do morto, uma vez que a água tem valor purificador, eliminando toda a sujeira e impureza da morte e do corpo físico, possibilitando que o indivíduo esteja limpo para o encontro com Deus. Por representar a purificação e a limpeza é que:

no meio hebraico, é recomendado renovar a água dos recipientes dos apartamentos nos quais morreu alguém e dos apartamentos contíguos; diz-se que os maus espíritos (djenuns) freqüentam os lugares nos quais há água: "Há espíritos mal feitores tanto nas fontes como nos campos", diz o Talmude. (BAYARD, 1996, p. 20)

O ritual de lavagem do corpo está presente em outras tradições, mas há uma interseção entre a cultura judaica e cristã durante o século XVIII em relação ao lavatio corporis, que ganha um caráter habitual e solene através do papel do clero como responsável pelos rituais fúnebres na Baixa Idade Média. Ariès explica que "não é improvável que a cerimônia de lavagem do corpo e o despejo das águas poluídas, recebida de um velho fundo pagão, tenha sido renovada por imitação daquilo em que se tinha transformado nos ritos dos monges" (1989, p.173).

No judaísmo, após a lavagem do corpo, esse é envolto em uma mortalha branca de forma que todo o corpo fique coberto. Nesse gesto não há distinção entre ricos e pobres, todos são sepultados da mesma maneira, em vestes simples e iguais, sem nenhum tipo de ornamento.

Nos funerais cristãos, até o século XII, o morto era apresentado descoberto, mas durante a Alta Idade Média o morto "se torna insuportável à vista", passando a ser coberto e a adotar também o uso do caixão. Segundo Philippe Ariès:

o corpo, depois da morte, após as expressões de luto e de pesar, era estendido
fosse sobre o tecido precioso, lençóis de ouro, tecido tinto de cores ricas,
vermelho, azul, verde, fosse mais simplesmente sobre o sudário, isto é, um
pano de linho, um lençol. Depois o corpo e o lençol eram colocados numa
padiola ou caixão, exposto durante algum tempo diante da porta da casa, e em
seguida transportado ao local da inumação. Pouco tempo depois da morte e no
próprio local desta, o corpo do defunto era completamente cosido na mortalha,

\footnotetext{
${ }^{8}$ Esses períodos iniciam após o sepultamento e são marcados cronologicamente em intervalos mais longos com o passar do tempo: primeira semana, primeiro mês, primeiro ano. Esses períodos correspondem a orações e obrigações específicas reforçando a memória do morto.
} 
da cabeça aos pés, de tal modo que nada aparecia do que ele fora, e em seguida freqüentemente fechado numa caixa de madeira. (1989, p.179-181)

No entanto, nos países mediterrâneos, a visão do rosto do morto não ganhou tal conotação desagradável que devesse ser escondido, encoberto. Por isso o uso da mortalha não se difundiu nesses países, sendo mantido, até os dias de hoje, o costume de velar o corpo descoberto.

Dessa forma, apesar do uso comum da mortalha, percebemos a diferença de seus significados: enquanto no judaísmo há a preocupação de manter a igualdade dos indivíduos perante a morte, no cristianismo há uma completa distinção entre ricos e pobres, pois os pobres estavam destinados a usar tecidos mais simples e os ricos mantinham sua posição social ao usar tecidos preciosos ou de cores que demonstravam o lugar que ocupavam na sociedade.

Não se descobriu ao certo quando tiveram início as diferenciações em relação à mortalha, lhe conferindo uma associação à tradição judaica, mas sabe-se que o tratamento e significado dos cuidados com o morto ganharam uma dimensão e uma sacralidade própria para cristãos e para judeus.

No cristianismo a santificação do corpo permanece, inclusive após a morte, e também está ligada a objetos e a relíquias. Acreditava-se, no período medieval, ser possível receber a santidade pelo contato, assim, os caixões eram colocados lado a lado, de forma contígua, para que se passasse a sacralidade àqueles enterrados próximos e assim por diante.

Dessa forma, podemos perceber uma perspectiva de preservação do corpo, reforçada consciente ou inconsciente pelo desejo de imortalidade do mundo ocidental. No judaísmo o corpo é cuidado para valorização da alma. Estabelece-se a crença da perpetuação da alma, que é libertada do seu meio físico com a decomposição do corpo. A mortalha representa uma veste igualitária, sem amarras, botões, metais, fechos etc. permitindo essa liberação.

A imortalidade da alma, na crença cristã, se apresenta com a preocupação de explicar os acontecimentos após a morte e de consolar as famílias e essa noção é reforçada pós-Idade Média. A própria descrição de paraíso reflete a crença de que seria possível o reencontro com os entes queridos que já se foram:

Na realidade, o que acreditamos ser algo novo no cristianismo, ou seja, a idéia de que nossos entes queridos nos observam e que voltaremos a vê-los, remonta aos primeiros séculos da Igreja, mais precisamente a São Cipriano, que 
expressou o desejo e a certeza de encontrar os seus do outro lado da vida: "Por que não nos apressamos e corremos para ver nossa pátria e saudar nossos ancestrais? Um grande número de entes queridos ali se encontra à nossa espera. Somos desejados por uma considerável multidão de pais, irmãos e filhos. Instalados doravante em condições seguras, eles se preocupam com nossa saúde. Poder vê-los e abraçá-los é uma imensa alegria para nós". (COMTESPONVILLE, et.al. 2006. p. 88)

Ambas as crenças coincidem, portanto, na valorização da alma e na importância de seu cuidado na construção da paz no mundo dos mortos, mas também dos vivos:

\begin{abstract}
Nessa visão de mundo (se refere à antiga civilização das aldeias e aos folcloristas ${ }^{9}$ ), o problema do terceiro local não se apresenta, ou muito pouco, ou melhor: ele já está resolvido. Os mortos estão diante da nossa porta, nos rodeiam, vivendo a vida deles, se podemos dizer, durante toda a seqüência que separa a morte física da sua liberação definitiva ${ }^{10}$, ritmada pelas etapas da sua decomposição, e ainda além. Uma vez que não é forçosamente expresso em termos de expiação de pecados, fica no entanto evidente que os mortos têm negócios a resolver, tanto com seus próximos como com a comunidade da qual são parte integrante. (VOVELLE, 2010, p. 31)
\end{abstract}

Vovelle trata do Terceiro Local, o purgatório, e sua invenção no imaginário medieval e moderno, principalmente nos registros das imagens. Percebe que permanece a crença de que bons ou maus, os mortos estão sempre aí, tanto no fim como no início da Idade Média (VOVELLE, 2010, p. 34) fazendo súplicas, solicitando orações, ajudas, prestações e tendo seu encontro temido com os vivos.

$\mathrm{O}$ advento da racionalidade a partir do século XVI e o início do protestantismo vão gerar um combate às ações mágicas do homem. Não vai haver um rompimento com a magia, mas ela se transforma na condução de respostas mais objetivas e menos sobrenaturais.

Essas crenças cristãs e judaicas que coincidem no período medieval e moderno vão sendo gradualmente diferenciadas. Rituais fúnebres singulares, que se perpetuaram em cada um desses grupos, vão traduzir sua permanência ou mesmo sua rejeição, estando relacionados aos contextos históricos de perseguição dos judeus durante os séculos XVI e XVIII como trataremos a seguir.

\title{
Medo e perseguição judaica
}

Em vários momentos e circunstâncias ocorreu a conversão de judeus às religiões cristãs. Durante o medievo essa conversão está relacionada a uma campanha antijudaica,

\footnotetext{
${ }^{9}$ Complemento nosso.

${ }^{10}$ Grifo nosso.
} 
associada ao combate às heresias e a reflexos da Guerra de Reconquista, no caso ibérico, pela Igreja Católica.

As conversões nem sempre foram forçadas, mas não eram comumente bem aceitas nem pelos judeus e nem pela sociedade conversora. $\mathrm{O}$ judeu converso recebeu a designação de marrano, que vai acabar configurando o aspecto pejorativo que trata a situação do converso como um problema (CALVO e SILVA: 2009).

Para a comunidade judaica, a conversão é o abandono da crença judaica, vista como traição da permanência do próprio grupo e de seu passado. Para a sociedade conversora, o converso é sempre impuro e suspeito na eterna desconfiança sobre a verdade de sua conversão.

Cascudo (2001) reafirma o caráter infiel do marrano, como ficou conhecido o judeu convertido, ao definir sua origem da abstinência de marrã (porco que terminou o aleitamento) numa denúncia clara em permanecer judeu e que trazia uma concepção negativa e uma cultura de mau-agouro:

Para "marrano" convergiu perversidade astuta e mesmo, na Provença, enfermidade contagiosa. Que marrano te agarre é expressivo em Portugal. Valia maldito, amaldiçoado, excomungado identicamente no Brasil. No Rio Grande do Sul marrano é gado inferior. (CASCUDO, 2001, p. 54)

Na citação a seguir, novamente de Cascudo, fica explícita a tradição coletiva na imagem do judeu que permaneceu como herança social de um ódio que justificava seu ataque. O marrano, o cristão-novo, era considerado misterioso e tenaz, era acusado de sacrilégios ao catolicismo a que tinha se convertido:

\begin{abstract}
Quando houve o tremor de terra, em janeiro de 1531, os frades em Santarém pregavam, semeando pavores do apocalipse. Foi Gil Vicente quem pacificou a terra e as almas. À primeira pregação, os cristãos-novos desapareceram e andavam morrendo de temor da gente. Eram culpados pelo terremoto. Matar o judeu era uma maneira de orar, penitenciar-se agradar a Deus. Processo universal de sublimação interior e consciência dogmática. Minha mãe, incapaz de matar uma galinha, apiedada de todos os sofrimentos alheios, opinando pelo lume do fogão, disse, com naturalidade das frases feitas, imemoriais e verídicas: - Tem fogo para assar um judeu! A imagem não era criação de minha mãe mas reminiscência instintiva, associando às chamas a figura convulsa do judeu supliciado. Minha mãe era sertaneja e morreu, maior de oitenta anos ignorando que se queimasse gente viva para salvar-lhe a alma. Mas a frase lhe veio aos lábios porque era uma herança lógica do mecanismo intelectual do passado. (CASCUDO, 2001, p. 90-91)
\end{abstract}

Para Maeso, apesar de muitos estudiosos relacionarem a definição de marrano como sinônimo de porco pela aversão judaica à carne deste animal, a definição de porco como marrano é posterior, reforçando o significado de impuro, sinônimo de "homem 
sujo" (1977, p. 19). Em hebraico o judeu converso tem a denominação de anus, "forçado", implicando à perseguição e a conversão forçada na Espanha e em Portugal no contexto da Inquisição Ibérica.

A Inquisição Ibérica tem uma relação direta com o poder das monarquias absolutas na Espanha e em Portugal numa associação entre Igreja e Estado, pautada numa cumplicidade popular que já manifestava discriminação, perseguição e ódio ao judeu.

Em um primeiro momento, o contexto ibérico, que era marcado pela agitação da massa pelo baixo clero na promoção de massacres aos judeus, serviu ao propósito de alertar os poderes constituídos para a "necessidade" de se estabelecer um novo mecanismo de controle social teologicamente orientado.

No momento posterior, a Igreja pactua com o Estado ao oferecer-lhe a Inquisição como um meio de canalizar a energia popular contra os judeus, associados como "agentes do diabo":

\begin{abstract}
Os saques aos judeus converteram-se em confiscos; as violações e pancadas foram regulamentadas em sessões de tortura; as perseguições de rua transformaram-se em procissões, nas quais os judeus, em vez de serem linchados, sofriam a humilhação moral do sambenito. E as fogueiras, antes improvisadas às pressas, organizaram-se em queimadores, erigidos em lugar e data previamente afixados. Essa espetacularização do massacre implicava numa sistematização da agitação caótica, numa seleção cuidadosa das vítimas, numa estilização da violência antes praticada a esmo pela turba. (NAZARIO, 2005, p. 34-35)
\end{abstract}

Dessa forma se institucionaliza a Inquisição como instrumento do Estado estabelecendo o Tribunal do Santo Ofício em 1478, na Espanha e em 1536, em Portugal. Algumas são as hipóteses sobre a chegada dos judeus ao local que hoje conhecemos como Península Ibérica, uma das mais antigas, antes mesmo da expansão do Império Romano e a paulatina ascensão do cristianismo como religião oficial, remete ao século XI a. c, quando o Rei babilônico Nabucodonosor II destrói o Primeiro Templo Hebraico (também conhecido como Templo de Salomão), obrigando grandes hordas de judeus a abandonarem suas casas e, via Fenícia entrar em embarcações rumo a travessia do Mar Mediterrâneo, é o que nos diz Martins (2015:9) “acredita-se que os primeiros judeus chegaram à Península Ibérica antes da Era Cristã, transportados por barcos fenícios, logo após a conquista de Jerusalém por Nabucodonosor e a destruição do Primeiro Templo hebraico no ano de 587 a.c.”. 
Ainda que seja esta uma hipótese rodeada de mistérios e profundas discussões historiográficas, as marcas da presença judaica na Espanha e em Portugal é indissociável do próprio baluarte historiográfico que envolve o processo civilizacional desses dois estados-nação. No entanto, para Martins (2015), os registros mais significativos dos judeus na península ibérica estão no século IV, quando esses povos já se encontram agrupados em comunidades. No Império Romano, os judeus se amalgamava com outros povos, tendo convivência harmônica com as culturas que formavam a população hispânica, se distinguindo apenas no campo das suas práticas religiosas, o que, no entanto, não foi motivo de conflito.

Posteriormente, ao caracterizar o período anterior à reconquista cristã da Península Ibérica, onde o período da conquista árabe, do século VIII ao XV, foi marcado pela prosperidade cultural, religiosa e econômica, Anita Novinsky (2015), em seu livro Os Judeus que construíram o Brasil: Fontes inéditas para uma nova história, nos diz que

No reino mulçumano, os judeus da Espanha participaram da prosperidade econômica, e vários fatores contribuíram para a sua proeminência no comércio internacional, como o fato de conhecerem muitas línguas, o que facilitava as negociações com outros povos (NOVINSKY, 2015, p.24).

Na Península Ibérica a relação entre judeus e cristãos se fez em meio a cenários paradoxais, envolvendo tanto o poder imperial, quanto as ordens e altos postos da Igreja, os conflitos e disputas de poder que envolviam os judeus, estiveram alocados em uma balança de complexo equilíbrio entre o poder temporal e o atemporal.

$\mathrm{Na}$ dimensão estratégica do poder imperial, os judeus, detentores de elevado conhecimento na área de cartografia, da matemática e da astronomia, foram exímios navegadores, com grande capacidade de localização, navegação e precisão geográfica, sendo os propulsores da expansão marítima portuguesa, qualidades essenciais e indispensáveis para que Portugal viesse a se expandir e fazer de Lisboa uma cidade sem par na expansão marítima. É o que nos diz Novinsky, quando ao analisar a importância dos judeus para a expansão marítima portuguesa, nos diz que

\footnotetext{
A navegação informal, sem bases científicas, foi transformada em um processo preciso com a elaboração de equações matemáticas complexas e instrumentos inovadores. Em 1500, podiam-se encontrar nas embarcações aparelhos capazes de medir localizações de maneira precisa, além de mapas quase perfeitos (NOVINSKY, 2015, p.24).
}

Consideramos que todo esse conhecimento acumulado e útil para a coroa, tenha feito com que até o século XV, Portugal tenha celebrado boa relação com a população judia que vivia em seu território, sendo que, nem mesmo as queixas provenientes da Igreja 
Católica, tenham conseguido ser eficazes e poluir os ares de tolerância que pairavam sobre o território português. Já na vizinha Espanha, marcada pela queda do último reduto muçulmano em 1492, quando a cidade de Granada é conquistada pelos reis católicos (Fernando e Isabel) e o clima de tolerância religiosa que já não era dos melhores, é rompido, os judeus passam a serem perseguidos e começa o grande fluxo de tentativa de travessia rumo a Portugal. Neste cenário ibérico, a tradição dos reis portugueses, marcada pela tolerância e pelo bom relacionamento com a Espanha, fez com que, por muito tempo, Portugal se contrapusesse às influências vindas da Espanha católica. Martins (2015), ao nos falar sobre os primórdios do discurso antijudaico na Península Ibérica e a sua relação com a inquisição, nos diz que

\begin{abstract}
A literatura antijudaica em Portugal só surge verdadeiramente após a introdução da Inquisição e os massacres são uma insignificante excepção ao clima de tolerância. [...] A tradição portuguesa sobreviveu a todas as investidas e tentações antijudaicas (particularmente as que vinham de Espanha) e os judeus puderam manter-se em clima aceitável até a criminosa emergência das perseguições inquisitoriais (Martins, 2015, p.23).
\end{abstract}

O que Martins (2015) mostra é que os monarcas portugueses, mesmo Dom Manuel I, tiveram uma política dúbia em relação aos judeus, isso porque por um lado sabiam da importância social e econômica que os judeus exerciam no reino, uma vez que “cabia aos judeus portugueses a ocupação das trocas, a gerência financeira das rendas régias e particulares, a participação fundamental nas atividades artesanais, a contribuição muito significativa para o erário régio através dos pesados impostos" (2015:22).

Por outro lado, a coroa sofria as pressões da vizinha Espanha e da Igreja Católica, essa temia a crescente influência judaica nas questões financeiras e administrativas do reino, o que ameaçava o império da religião. Os reis portugueses, sabedores dos benefícios econômicos em manter os judeus em solo, direcionaram suas políticas no intuito de amortizar as coações provenientes principalmente da Igreja Católica, em 1506 a insustentabilidade dessa política de "pesos e contrapesos" é marcada com a brutalidade institucional, "só a pressão das ordens religiosas, sobretudo os dominicanos, levaria mais longe o antijudaísmo. Foi assim que eclodiu, em Abril de 1506, o pior massacre de judeus portugueses, onde pereceram milhares de cristãos-novos." (2015:24).

Nesse contexto perverso, tanto para o judeu como para o judeu converso, é que acreditamos que se estabeleceu a diferenciação do rito funerário cristão para o judaico em relação à utilização da mortalha. $\mathrm{O}$ judeu, e principalmente o criptojudeu - o converso que mantinha práticas judaicas em segredo, era temido e associado a tudo que era negativo e agourento. Essa visão negativa vai levar gradualmente à substituição das práticas 
específicas judaicas e a implicação, no caso do indicativo da permanência dessas práticas, à acusação de crime de judaísmo.

A carta monitória de Dom Diogo da Silva, durante a visitação do Santo Ofício na Bahia nos anos de 1591 a 1593, arrola uma série de práticas e cerimônias judaicas que incidiam na categoria de crimes a serem confessados ou denunciados. Incluía guarda de dias sagrados, rituais como jejuns, recusa ao consumo de certos alimentos, mas também práticas mortuárias como se vê:

\begin{abstract}
O tratamento e o sepultamento dos cadáveres, e o luto segundo o costume judaico. Comer em mesas baixas durante o nojo (luto); banhar e vestir os defuntos com roupa de linho; vesti-los com compridas camisolas, cobrindo-os de mortalhas dobradas à guisa de capas; o enterro do falecido em solo virgem e em sepultura bem funda, o canto de litania de acordo com a tradição judaica - parte ritual do luto; colocação de uma pérola-semente ou moeda de prata ou ouro, na boca do defunto, destinados ao pagamento da sua primeira pousada; cortar as unhas do defunto; esvaziar moringas, potes de barro e demais vasilhas de água, após a morte de uma pessoa, expressão da crença de que a alma do defunto viria banhar-se ali, ou que o Anjo da morte ali estivesse lavando a espada com que golpeara. (citado por WIZNITIZER, 1966, p.11-12)
\end{abstract}

No caso brasileiro, apesar das orientações da Igreja, vão perpetuar muitas dessas práticas como costume, predominantemente nas cidades interioranas da tradição colonial. Isso se deu, principalmente, pela distância entre colônia e metrópole.

Até hoje é possível perceber hábitos como a lavagem do morto, o uso da mortalha e a preferência por terras virgens, que não receberam outro corpo anteriormente, nos rituais funerários pelo sertão do Nordeste e cidades do interior do estado de Minas Gerais, como em Sabará e regiões do norte de Minas.

A conservação de certos hábitos rituais faz parte da cultura dos brasileiros e podem ser explicadas pela teoria do homem dividido, de Anita Novinsky, em que o cristão-novo "vivia no primeiro sem ser aceito, era identificado com o segundo sem o conhecer. Se era judeu para os cristãos, o que era para os judeus?” (NOVINSKY, 1992, p. 7).

O cristão-novo, categoria do judeu converso em Portugal como status social pautado na pureza do sangue cristão vai, no Brasil, seguir o catolicismo sob permanência das práticas culturais do antigo judaísmo (conscientemente ou não) que lhe dariam uma ligação com sua origem e constituiriam sua identidade no novo mundo. 


\section{O segredo e a tradição: a mortalha nos inventários e testamentos do século}

\section{XVIII, em Minas Gerais}

Os réus foram acusados de manterem, em segredo, a fé judaica mesmo após sua conversão, no entanto, não há, nos testamentos, nenhum indício da manutenção de relação com o judaísmo, com exceção do pedido de ser amortalhado em hábitos das irmandades a que pertenciam.

Até aqui não havíamos adentrado, propriamente dito, à noção de segredo, embasada aqui pelo texto de Simmel "O segredo"; é importante destacar que os cenários anteriormente descritos, sem áureas de mistérios, rente à racionalidade dos acontecimentos dos fatos, teve a sua trama tecida em matizes políticos, teológicos envoltos numa redoma de intenções e segredos, que ao cerzir religião e política despertou toda uma força teológica antijudaica que se propagou através de Portugal ao Brasil.

Novinsky (2015:45) nos diz que "os judeus foram o único povo do mundo para o qual foi criado um Tribunal especialmente voltado para vigiá-los e puni-los: o Santo Ofício da Inquisição." Ao analisar os engendramentos deste tribunal, no intuito de compreender as engrenagens que o fazia funcionar, ou seja, quais eram os mecanismos de denúncia que garantiam o seu movimento, a autora diz que aquilo que acontecia dentro do tribunal não poderia ser levado a público, de tal maneira "a inquisição introduziu, na civilização portuguesa, uma 'cultura do segredo' que predispunha o povo à dissimulação.” Nesse sentido, Simmel (1999) nos diz que

\section{O segredo situa a pessoa numa posição de exceção; opera como uma atração pura e socialmente determinada. É basicamente independente do conteúdo que guarda, mas naturalmente torna-se cada vez mais efetivo na medida em que a sua posse exclusiva ganha em amplitude e em significado (Simmel, 1999)}

As delações em caráter de segredo, dissimulações despertadas na comunidade por meio do Tribunal da Inquisição, quebra a cadeia natural das relações dentro de uma sociedade, obrigando os indivíduos a silenciar ideias e emoções, aumenta-se o estado de alerta e de desconfiança mútua, faz com que práticas sejam emudecidas e a perpetuação deste silêncio, como forma de autoproteção, leva ao esquecimento de cerimônias, rituais e celebrações. O segredo em si, ainda que em algumas situações possa vir a ser um invólucro vazio, coloca a comunidade e suas práticas dentro de um arranjo de exceção, de perigo diante do próprio vizinho e, esse medo, ao se espalhar, insuflam de forças a Igreja Católica, instituição que por meio do discurso de fé, atribui valor de segredo às práticas que lhes são estranhas. Novinsky (2015) destaca que a cultura do segredo tem nas mulheres uma das suas principais marcas, uma vez que ao serem proibidas a 
existência das sinagogas, as práticas são continuadas nas entranhas dos seus lares, sendo que esses lares foram o principal foco do olhar inquisitorial do Tribunal da Inquisição.

A Igreja Católica, ao utilizar o discurso litúrgico onde as explicações que tinha como foco a empiria e a razão, eram associadas ao exercício de feitiçaria, cria todo um imaginário místico-religioso em torno das práticas judaicas, de maneira que aos fiéis católicos, a Igreja acusava os judeus de hereges, de estarem profanando a "divina escritura" por meio de cerimônias relacionadas à "Lei de Moisés", praticadas no segredo dos seus lares. Sendo que o papel redentor, não dos corpos, mas das almas judias, a purificação dos pecados, caberia à igreja, transmutação que aconteceria via punições e sequestro do bens materiais dos judeus. ${ }^{11}$

Ao analisar o cenário social, econômico e político português até o século $\mathrm{XV}$, onde os judeus se projetaram pela grande influência na gestão imperial, marcados principalmente pelos seus conhecimentos econômicos, matemáticos, médicos, etc. o que podemos compreender é que toda essa ascensão relativizava o poder da Igreja, essa, valiase do aspecto sigiloso em torno das práticas judaicas, para inflamar a imaginação dos fiéis, atribuindo infortúnios à presença judaica na cidade. Na perspectiva do imaginário religioso que pode se tornar prática social, Simmel (1999) diz que "diante do desconhecido, o impulso natural do homem em idealizar e o seu temor natural cooperam para com o mesmo objetivo: intensificar o desconhecido através da imaginação e dar-lhe uma ênfase que nem sempre corresponde à realidade patente. "Ao analisarmos os libelos inquisitoriais, percebe-se que diante da resposta afirmativa ou negativa, ou seja, pelo "sim” ou pelo "não", inevitavelmente, os judeus sofreriam severas punições, vemos que:

O réu era interrogado através de questionamentos como: "se em algum tempo havia se distanciado da Fé Católica e se passara a crer na Lei de Moisés, buscando nela a salvação da alma; se rezava as orações judaicas ou as cristãs,

\footnotetext{
${ }^{11}$ Para ilustrar o que estamos dizendo, trazemos o trecho do ocorrido no ano de 1506, em Lisboa, na Igreja dos Dominicanos, em pleno Rossio. "Constava que um milagre se manifestara, no dia 15 desse mês, naquele templo dominicano. A vontade de crer era demasiado forte para descrer em qualquer sinal, por pequeno ou inacreditável que fosse. [...] Não se podia desperdiçar uma fugaz manifestação divina. E aconteceu. O sinal implorado com toda a convicção repetiu-se. Uma luz brilhou, incandescente, no crucifixo da capela da Igreja. Todos viram. Todos rejubilaram. Todos se sentiram recompensados pela crença profunda e sincera. Todos? Não. Na verdade, houve um que ousou duvidar da natureza divina da luz. Teria sido o reflexo de uma das muitas candeias acesas naquele convento, para chamar a atenção do Omnipotente. Incautamente, proferiu as palavras proibidas, indesejadas, demolidoras da esperança compensada. Era um cristão-novo. Heresia! [...] mal proferiu a contraproducente "blasfémia", o povo caiu sobre ele, arrastou-o para a rua e agrediu-o barbaramente até cair inanimado. Prostrado no Largo de S. Domingos, foi identificado pelo irmão, que se debruçou sobre o seu cadáver e gritou lancinantemente: "Quem matou meu irmão?!". Acto contínuo, foi igualmente executado pela turba, que, de pronto, acendeu uma fogueira e queimou os dois infelizes cristãos-novos. Num clima de intolerância crescente, enquanto o povo se aglomerava em torno da redentora fogueira, aos quais se juntariam mais dois frades dominicanos, Frei João Mocho e Frei Bernardo, exibindo o crucifixo "milagreiro" e fazendo apelos sanguinários contra os judeus: "Heresia! Heresia! Destruam o povo abominável!...” (MARTINS, 2015, p.33-34).
} 
sem mencionar Jesus no fim; se guardava os sábados; se seguia a Páscoa dos judeus; ou se fazia algum jejum judaico" (Novinsky, 2015, p.50)

Se o indiciado pelo tribunal responde de maneira negativa à acusação, seria sentenciado como sendo mentiroso, se a sua resposta era afirmativa às práticas que estava sendo acusado, seria ele condenado da mesma maneira. Nota-se que a delação em si já era considerada prova de crime, uma vez que independentemente da resposta, o réu era tido como traidor.

É nesta perspectiva que analisamos a relação entre segredo e traição, tendo como perspectiva o trecho onde Simmel (1999) diz que "de modo bastante peculiar, os encantos do segredo estão relacionados com os do seu oposto lógico, a traição - que evidentemente não são menos sociológicos. O segredo contém uma tensão que se dissolve no momento da revelação." Os “Autos de Fé”, mais que uma punição, era o momento de evidenciar a identidade do grupo ao qual o "traidor" pertencia, deixando-o como exemplo aos demais que ousasse praticar o judaísmo, essa prática terrorista da Igreja Católica, era, nas palavras de Novinsky (2015:46), "um novo sistema para glorificar o extermínio dos judeus, estabelecendo um clima de festa popular. Esses espetáculos reuniam a massa que, como divertimento, via agonizar os acusados."

É neste aspecto simmeliano do segredo, que o Tribunal da Inquisição é aqui pensado. Para Novinsky (2015:49), o referido tribunal teve como principal objetivo vigiar e punir as práticas judaicas, isso porque "o processo inquisitorial era atípico e corria em segredo. O réu não era informado sobre as razões da prisão ou sobre quem eram seus denunciantes"; por meio deste órgão eclesiástico eram "encontrados" os traidores da fé, esses eram submetidos à confissão de traição, sendo seus bens confiscados, quando não confessavam a traição eram condenados a sessões de tortura. ${ }^{12}$

Em Minas Gerais o segredo, tal qual pensando através do texto de Simmel, foi uma maneira de produzir silêncios e, na longa duração, uma via de reforçar os esquecimentos, isso porque a sociedade fortemente cristianizada, deixou o judaísmo como religião restrita aos lares, fazendo com que as práticas judaicas em Minas Gerais fossem se esmaecendo, diluindo no tempo, sendo eclipsada pelo catolicismo, é nesse aspecto que Novinsky (2015: 169) diz que “embora um certo número tivesse forte apego

\footnotetext{
12 Novinsky (2005: 51) [Assim relata as condições duas das torturas aplicadas pelo Tribunal da Inquisição: “Os presos que demoravam a confessar ou se negavam a assumir o judaísmo eram submetidos a sessões de tormento. As torturas usadas no Tribunal de Lisboa foram o potro e a polé. A polé consistia em uma corda pela qual o réu era içado e sacudido violentamente, deslocando os ombros. O potro era uma bancada onde era preso por cordas, acionadas por uma manivela, que estrangulava suas articulações.]
} 
ao judaísmo, havia no Brasil um alto grau de cristianização por parte dos conversos, principalmente aqueles que se encontravam entre os fundadores das vilas do ouro."

Assis (2012), ao analisar os processos da Ana Rodrigues e seus descendentes, conhecida como Senhora de Mantoim, na Bahia, e matriarca da família Antunes. Uma poderosa família da região, possuidora de prestígio, poderio econômico, bons contatos, mas principalmente, fama de judaizar em segredo. Ana Rodrigues foi denunciada por um conjunto de costumes considerados estranhos ao catolicismo dominante e arrolados no Monitório inquisitorial como características de judaísmo.

Tais práticas consideradas estranhas incluíram costumes dietéticos (o fato de não comer certo peixe e evitar determinados alimentos como carne no luto, coelho, cação, arraia), adotar o processo de limpeza da carne e a fabricação de pães sem fermento que foram oferecidos a outros. No luto "prantear de modo judaico", não comer em mesas e não comer carne, se colocar detrás da porta, levantar a saia e sentar com o corpo no chão, amortalhar os mortos e esvaziar os potes de água. Trocar as vassouras, jurar pela alma dos falecidos lamber os netos, correr com as mãos pela moleira e testa abençoando os filhos e netos, cozinhar na sexta feira, acender as velas, proceder a higiene de si e da casa neste dia e descansar no sábado.

A mortalha realizada por Ana Rodrigues e seus descendentes, assim como também pelos réus de Sabará, é uma das permanências que se estabeleceram no Brasil, assim como rituais da toalete fúnebre e cercado por superstições em torno da morte. Cascudo registra suas lembranças sobre os costumes brasileiros do luto:

\footnotetext{
Para as mulheres, vestiam as longas camisas brancas. Nos homens, para iludir a vigilância suspicaz do Santo Ofício, envergavam um hábito de S. Francisco em cima do traje que o costume sagrara. Não podia acompanhar o corpo nenhum objeto metálico. Agulhas, alfinetes, a cruz dos terços, depois os dentes obturados a ouro, eram retirados, respeito que veio às primeiras décadas do século XX. Os oficiais eram enterrados com as fardas sem botões dourados. Dedos sem anéis para defuntos e defuntas. Sapatos sem pregos, ou sandálias de feltro, pano grosso, ou embrulhados os pés numa toalha. Muitos desses pormenores constituem usos brasileiros. Os lenços, vestidura fúnebre, cobrindo inteiramente o cadáver, inclusive a cabeça, foi uma tradição respeitada nos sertões e mesmo nas cidades. O sábio Oswaldo Cruz, falecido em 1917, amortalhou-se dessa forma. (2001, p. 96)
}

Bayard (1996), identifica o uso da mortalha nos ritos mortuários como uma questão cultural percebida em três grandes povos - egípcios, em tribos de pigmeus da África Central e judeus, e também em algumas tribos indígenas na América, que 
envolviam o cadáver em pele de animais - chamado de fardo, e na ilha de Madagascar, em que o corpo é envolvido em um sudário ${ }^{13}$.

Na maioria dos testamentos analisados por Calvo e Silva (2009) o amortalhamento foi solicitado em hábito de São Francisco, o preferido e citado também em estudos sobre a morte na Bahia de João José Reis (1991) e Adalgisa Arantes Campos (1988):

São Francisco aparece numa oração popular de origem portuguesa como portador de uma carta de Madalena, a pecadora arrependida, a Cristo. Nessa mesma oração, que nada menciona sobre morte ou julgamento divino, há uma alusão, em tom afetivo e sem nexo aparente, à roupa do santo. (REIS, 1991, p. 118).

Para Reis, a mortalha e o uso do hábito de S. Francisco remetem a um costume português, difundido principalmente no Brasil por mulheres. Já para Campos, que também aponta a recorrência de sua solicitação em vários testamentos das minas Setecentistas, "a mortalha era outro símbolo social exterior. (...) As mortalhas eram caras e os que não se encontravam preparados para este gasto tinham que se contentar com um lençol” (1988, p. 17), já indicando as formas de apropriação de seu uso na cultura brasileira.

A relação cristã se relaciona à uma tradição e também pode ser vista como estratégia ligada ao segredo e à perpetuação de tradições que afirmavam aos judeus quem eram e seu pertencimento cultural e identitário por meio da relação com suas origens judaicas e, certamente a construção de novas origens singulares na América portuguesa.

\section{Considerações finais}

A mortalha tem forte presença nos rituais fúnebres. Afirmada como judaizante pela Inquisição, se tornou proibitiva no reino e abandonada na relação de desprezo e no processo de buscar afastamento e distinção do judeu e do judeu converso.

Entretanto, no Brasil fazia parte da cerimônia do luto, inclusive com a orientação do modelo ${ }^{14}$ herdada do contato dos hebreus com os egípcios na antiguidade, e apoiada

\footnotetext{
${ }^{13}$ Segundo o dicionário eletrônico Houaiss de língua portuguesa, mortalha e sudário tem significados semelhantes. A palavra "sudário" tem origem no latim e seu uso remonta ao século XIV. Um de seus significados é "espécie de lençol com que se envolve o cadáver; mortalha" ou ainda "véu que se usava antigamente para cobrir a cabeça dos mortos". Já a palavra "mortalha", que também tem origem no latim e remonta ao século XIII, tem como significado "pano ou vestimenta com que se envolve o cadáver de pessoa que será sepultada" e ainda "hábito usado por monge ou monja".

${ }^{14}$ Segundo Cascudo (2001) "usual era a mortalha de manto ou lençol inteiro, envolvendo todo o cadáver, sem costurar-se mas amarrando-se com atilhos, como vemos nos quadros da ressurreição de Lázaro, modelo
} 
pelo culto cristão ao consolidar o sincretismo com a solicitação de se colocar por cima o hábito de S. Francisco.

As perseguições compuseram um registro de desgraças e destruição ao longo da História para os judeus, mas paradoxalmente, como nos indicam as permanências dos hábitos de luto judaicos no Brasil, acabaram por dar sentido à dispersão e a disseminação de influências culturais que perduram e se perpetuam como contribuição da tradição judaica ao nosso país.

Gorestein (2005) indica as dificuldades de manutenção do judaísmo na colônia

As regras e costumes da Lei de Moisés se apagavam gradualmente da memória, à medida que a comunidade cristã nova ficava cada vez mais isolada do mundo oficial judaico fora da Península Ibérica [...] as dificuldades de comunicação, proibição de manutenção de escolas, do ensino da Bíblia e do Hebraico, principalmente o perigo mortal de ser descoberto pela Inquisição, limitaram as práticas judaicas às poucas leis mantidas na memória. Não era um judaísmo nem profundo, nem ortodoxo, era uma transmissão oral de conhecimentos daqueles que conheciam melhor as tradições judaicas. $O$ fato de serem educados como cristãos fez com que o judaísmo se mesclasse com o cristianismo, formando o que Cecil Roth determinou "religião marrana". (2005:153)

É justamente essa característica sincrética que marca as tradições da mortalha e outras tidas como judaizantes no caso dos réus de Sabará. Não há elementos na documentação e nem no processo inquisitorial, a não ser a imputabilidade de culpa feita pelo inquisidor, que comprovem uma ligação com o judaísmo profundo revelando uma rejeição do catolicismo enquanto prática religiosa.

As ritualísticas se parecem mais como tradições e crenças familiares e "gestuais mágicos" do que propriamente uma tentativa de se manter vinculado a uma religião em segredo. No caso da mortalha e no fato dela ter se propagado como prática regional (incluindo uma escrava forra não nascida nas tradições judaicas) nos leva a pensar que não havia aí nenhum estranhamento ou mesmo tentativa de segredo.

O imaginário que a proíbe se assenta no medo das tradições demoníacas e da própria figura do marrano como analisamos neste trabalho. Para o morador de Sabará é um sincretismo de práticas passadas de geração para geração, que protegeria os vivos e garantiria conforto e continuidade da alma ao morto.

Criminalizar a prática se associa a uma regra maior, instalada pela Igreja e pelo Estado português, sob intenções políticas mais que religiosas, afim de normatizar e normalizar uma prática e coibir a magia, os desvios de toda forma, ritual, ou gesto, voltada 
para criar uma forma de ser (e de não) português católico, civilizado e seguidor da moral e dos bons costumes.

\section{Referências}

ARIÈS, Philippe. Sobre a história da morte no Ocidente desde a Idade Média. 2. ed. Lisboa: Teorema, 1989.

ASSIS, Angelo Adriano Faria de. Macabeias da Colonia: criptojudaismo feminino na Bahia. São Paulo: Alameda Editorial, 2012.

BAYARD, Jean-Pierre. Sentido oculto dos ritos mortuários: morrer é morrer?. São Paulo: Paulus - SP, 1996. 321p.

BARCELAR, Carlos. Uso e mau uso dos arquivos. In: PINSKY, Carla Bassanezi (org.). Fontes Históricas. São Paulo: Contexto, 2010. p.p.23-79

BOSCHI, Caio César. Irmandade, religiosidade e sociabilidade. In: RESENDE, Maria Efigênia Lage de; VILLALTA, Luiz Carlos (org.). História de Minas Gerais: As Minas Setecentistas 2. Belo Horizonte: Autêntica; Companhia do Tempo, 2007. p. 5975 .

Os leigos e o poder. São Paulo: Ática, 1986. 254 p.

Exercícios de Pesquisa Histórica. Belo Horizonte: Editora PUCMINAS, 2011.

CALVO, Júlia, SILVA, Bárbara Luana. Ritos mortuários e origem judaica: paradoxos entre a perseguição e a persistência no Brasil setecentista. Revista de Estudos

Judaicos. Belo Horizonte, IHIM: 2012. V. 9, p. 97

. O Marranismo como Fenômeno Histórico: Presença Judaica em Minas Gerais do Século XVIII. Revista de Estudos Judaicos. Belo Horizonte: Instituto Histórico Israelita Mineiro, 2009 .ano XI. N. 8. p. 120-133.

CAMPOS, Adalgisa Arantes. Considerações sobre a pompa fúnebre na capitania das Minas - o século XVIII. Revista do Departamento de História da UFMG. Belo Horizonte: Ed. UFMG, 1988. p. 109-22 (N.6)

CARNEIRO, Maria Luiza Tucci. Preconceito Racial em Portugal e Brasil Colônia. São Paulo: Perspectiva, 2005. 327 p.

CASCUDO, Luis da Camara. Mouros, Franceses e Judeus. Três Presenças no Brasil. 3 ed. São Paulo: Global, 2001. 115 p.

COMTE-SPONVILLE, Andre; DELUMEAU, Jean; FARGE, Arlette. A Mais Bela História da Felicidade: A recuperação da Existência Humana diante da Desordem do Mundo. Rio de Janeiro: Difel, 2006.

DELUMEAU, Jean. História do Medo no Ocidente. São Paulo: Companhia das Letras, 2009. $672 \mathrm{p}$.

FERNANDES, Neusa. A inquisição em Minas Gerais no Século XVIII. Rio de Janeiro: Eduerj, 2000. 212 p. 
GORENSTEIN, Lina; CARNEIRO, Maria Luiza Tucci. Ensaios sobre a intolerância: inquisição, marranismo e anti-semitismo. 2. Ed. São Paulo: Associação Editorial Humanitas, 2005. 442 p.

Um Brasil subterrâneo: cristãos-novos no século XVIII. In: GRINBERG, Keila (org.). Os judeus no Brasil: Inquisição, Imigração e Identidade. Rio de Janeiro: Civilização Brasileira: 2005, p.p. 138-160.

MAESO, David Gonzalo. A respeito da Etmologia do vocábulo "Marrano" (criptojudeu). In: NACHMAN, Falbel; GINZBURG, Jacó (org..). Os Marranos. São Paulo: Universidade de São Paulo/Faculdade de Filosofia, Letras e Ciências Humanas/Centro de Estudos Judaicos, 1977. p. 9-21 (n. 4)

MARTINS, Jorge. Breve História dos Judeus em Portugal. Lisboa: Editora Nova Vega, 2015.

NAZARIO, Luiz. Autos-de-Fé Como Espetáculos de Massa. São Paulo: Humanitas/ Fapesp, 2005. 207 p.

NOVINSKY, Anita. Cristãos Novos na Bahia. São Paulo: Perspectiva, 1992. 260 p.

Inquisição: prisioneiros do Brasil - séculos XVI a XIX. 2. ed. São Paulo: Perspectiva, 2009. 248 p.

. Ser marrano em Minas Gerais. Revista Brasileira de História. São Paulo. V. 21, n. 40, 2001. p.161-176.

NOVINSKY, Anita; CARNEIRO, Maria Luiza Tucci. Inquisição: Ensaios sobre Mentalidade, Heresias e Arte. Rio de Janeiro: Expressão e Cultura; São Paulo: EDUSP, 1992.

NOVINSKY, Anita; KUPERMAN, Diane (org.). Ibéria-Judaica: Roteiros da Memória. Rio de Janeiro: Expressão e Cultura; São Paulo: EDUSP, 1996 (América: Raízes e Trajetórias; v. 6).

NOVINSKY, et. al. Os judeus que construíram o Brasil: fontes inéditas para uma nova visão da história. São Paulo: Planeta do Brasil, 2015.

POLIAKOV, Léon. A Demologia Milenarista, Judeus e Jesuítas. In: A Causalidade Diabólica I. São Paulo: Perspectiva: Associação Universitária de Cultura Judaica, 1991. p. 29-53.

De Cristo aos Judeus da Corte: história do anti-semitismo I. 2.ed. São Paulo: Perspectiva, 2007. $258 \mathrm{p}$.

RAGO, Margareth, GIMENES, Renato A. de Oliveira. Narrar o passado, repensar a história. Campinas: UNICAMP, Instituto de Filosofia e Ciências Humanas, 2000. p.p. $9-10$

REIS, João José. A Morte é uma Festa: ritos fúnebres e revolta popular no Brasil do século XIX. São Paulo: Cia das Letras, 1991. 357 p.

SALVADOR, José Gonçalves. Os cristãos-novos em Minas Gerais durante o ciclo do ouro (1695-1755) - relações com a Inglaterra. São Paulo, Pioneira, 1992. 197 p.

SARAIVA, António José. Inquisição e Cristãos Novos. Lisboa: Editorial Estampa, 1985. 319 p. 
Ritos mortuários e origem judaica: paradoxos entre a perseguição e a persistência no Brasil setecentista. Revista de Estudos Judaicos (Belo Horizonte), v. 9, p. 79-97, 2012.

SIMMEL, Georg. O Segredo. Revista Política e Trabalho. Traduzido por Simone Carneiro Maldonado. Paraiba: Programa de Pós Graduação em Sociologia. da Universidade Federal da Paraiba, 1999. N. 15 (Disponível em: http://periodicos.ufpb.br/index.php/politicaetrabalho/article/view/6442)

VAISENCHER, Semira Adler. O enterro Judeu. In. http://semiraadlervainsencher.blogspot.com.br/2009/05/enterro-judeu.htm. Acesso em: março de 2012.

VAINFAS, Ronaldo; FEITLER, Bruno; LAGE, Lana (org.). A Inquisição em xeque: temas, controvérsias, estudos de caso. Rio de Janeiro: EdUERJ, 2006. 280 p.

VOVELLE, Michel. As almas do PURGATÓRIO ou o trabalho de luto. São Paulo: Unesp, 2010.

WIZNITZER, Arnold. Os judeus no Brasil colonial. São Paulo: 1966. 218 p.

ZUCHIWSCHI, José. Longe de ti Apagar nossas Lembranças: as palavras e as preces no luto judaico. Religião e Sociedade. Rio de Janeiro, 2010. n. 30 (1). p. 165-187. 